\title{
Cooperative learning on the web: A group based, student centred learning experience in the Malaysian classroom
}

\section{Mai Neo \\ Multimedia University, Malaysia}

This paper presents a multimedia mediated, student centred learning environment which seeks to study the group based, cooperative learning paradigm, using a web based multimedia project. This project is carried out in a Malaysian classroom by groups of students in the second year course in the Faculty of Creati In the cooperative learning environment, students are grouped in small learning teams to solve a problem or to perform a task that is presented to them by the teacher. This learning environment, however, uses a web based multimedia project as the core of study, and is a variation of the studen team learning techniques proposed by Slavin (1994) using project based learning. Students in the group cooperate and work among themselves, help each other to build the web based project, and then receive a group performance score. The overall objective of this 9-week study is to provide students with a group based, student centred, cooperative learning experience, and to investigate its impact on student learning. A survey was given to the students to ascertain their reactions and perceptions to this learning environment. Some students' works were also showcased. Results obtained were positive and encouraging.

\section{Introduction: Using ICT in teaching and learning}

In recent years, information and communication technologies (ICT), in particular, multimedia technology, have increasingly altered the landscape in our educational field, particularly in higher education. It is affecting communication strategies in the education environment. It is leading to the evolution of new concepts and innovative teaching techniques in the instruction-learning process. This infusion of ICT and multimedia technology into education has created a significant impact on instructional content development, and the methods of communicating information to the learners. It is changing the way teachers teach and students learn. 
This ICT revolution is fast changing the world, and creating a generation that is media hungry and technologically savvy. ICT is also fast gaining popularity in the education field as a means for creating a better teaching and learning environment. The marriage of content and technology not only provides the teacher with a more effective way to transfer knowledge and information to students, but also enables students to learn in a more productive way. In education, advances in computing and multimedia technologies have resulted in creating an emerging breed of technologically proficient learners. This new generation of learners is using digital media for learning and for communicating (Tapscott, 1998).

In the web based cooperative learning experience described in this article, multimedia authoring tools, Internet communication tools such as email FTP and chatrooms, and web based authoring tools including Dreamweaver and Flash, are used by technologically proficient students to undertake their projects.

\section{Cooperative learning: The pedagogical perspective}

Cooperative learning is a method of instruction whereby students grouped in small learning teams work in cooperation with each other to solve a problem, or to perform a task presented by the teacher (Johnson \& Johnson, 1986; Johnson, Johnson \& Smith, 1991; Slavin, 1991). Students in the group then work among themselves, help each other to achieve the group goal, praise and criticise one another's contributions, and receive a group performance score.

The roots of the cooperative learning model can be traced back to the works of Dewey (1916) and Thelan (1954) in the early 20th century. Dewey (1916) in his book Democracy and Education conceived the idea that classrooms should mirror the larger society, and function as a laboratory for real life learning, whereby students can participate in small groups and learn democratic principles and behaviour through daily interactions with each other. Thelan $(1954,1963)$ provided a more precise structured form of group investigation, and laid the foundation for contemporary developments in cooperative learning. Both Dewey and Thelan regarded cooperative group work not only as a means to improve academic learning, but also cooperative behaviour and processes, as a part of human endeavour to build and maintain a strong democratic society. Thus, according to them, the way to achieve this aim was to structure classrooms and student learning activities based on the model of cooperative learning.

In the traditional classroom in higher institutions of learning, students are usually expected to sit passively and listen to a professor deliver his or her expert educational content. Students expect to be evaluated on the basis of 
their individual work in quizzes, assignments, examinations and tests. Each student competes with peers to obtain the highest score that can be achieved individually. There is seldom use of interactions among the students, and rarely any opportunities to work together as a team in their learning. However, cooperative learning as an alternative to the traditional learning mode may improve student learning outcomes, and encourage development of team skills.

Arends (1997) described this learning model as characterised by cooperative task, goal and reward structures. A cooperative task is one that contains a single common goal that all group members aspire to attain. In this learning environment, students must cooperate and work together in teams to accomplish a common task. In this learning mode, the reward systems are group oriented rather than individually oriented as in the traditional, directed instruction method. In other words, to be effective, cooperative learning must create a situation in which students will interact with each other, share ideas and discussions, and strive to work together to achieve the shared group goals, rather than competing with each other for individual accomplishment. The teacher, on the other hand, acts as a 'consultant' or guide to support their learning, rather than as an 'expert' as in the traditional method of learning.

The best argument for cooperative learning is that it increases cognitive achievement and fosters social and team building skills. Johnson \& Johnson (1994) have indicated that cooperative learning approaches lead to (a) higher academic achievement than competitive or individual approaches, (b) better interpersonal relationships among students, and (c) more positive attitudes towards the subject being studied and the overall classroom experience. Slavin (1990) reported that in 49 out of 68 studies, the results favoured cooperative learning, compared with traditional methods.

\section{Class organisation}

This cooperative web learning environment was created in order to identify and cultivate among the students skills such as teamwork and leadership, communications, project management, confidence in decision making and negotiations, and capability in performing, developing and presenting. The study group comprised 58 students $(\mathrm{N}=58)$ from the Courseware class, who were in their second year in the Faculty of Creative Multimedia (FCM), majoring in Digital Media. These students had studied courses in design and web tools in their previous years, and were a mix of male and female students, and of Malay, Chinese and Indian racial origins. The overall objective for this 9-week study was provide students with a group based, student centred, cooperative learning experience, and to 
investigate its impact on their learning. The project description that follows below is structured by using six phases of a cooperative learning process, as defined by Arends (1997).

\section{Phase 1: Presenting the goal}

The project that was to be undertaken by the class involved applying their knowledge of learning theories to creating an educational website from which the whole class could study. By relating the project to their own learning processes, students would be able to perceive the project as authentic and be more engaged with it (Herrington, Oliver \& Reeves, 2003). By becoming more engaged with the project, they would be able to effectively construct knowledge, work cooperatively and collaboratively together, and determine their own learning outcomes (Neo \& Neo 2001). The project involved 3 phases: the Research Paper (Stage 1), the Website (Stage 2) and the Homepage (Stage 3).

\section{Phase 2: Presenting the information}

Students were given lectures on learning theories and their prominent theorists, to give them some background knowledge on the topics. These lectures also helped them to understand the materials on learning theories and theorists that they obtained from the Internet for their Research Paper (Stage 1) requirements.

\section{Phase 3: Forming student teams}

Formation of the student team was carried out basically in accordance with Slavin's (1994) methodology, with some variations. Team formation in this study consisted of:

- Stage 1: Small Group Formation and Research Paper. Here the 58 students $(\mathrm{N}=58)$ were divided into 29 pairs. Each pair had to select a learning theorist of their choice and write a research paper on the theorist's work. Teams were given 3 weeks to complete this task.

- Stage 2: Learning Theory Group formation, election of Group Leaders and creation of learning theory website. During this stage, several activities were undertaken. Firstly, the pairs were grouped into 3 main learning theories groups, Behaviourist (as characterised by theworks of Skinner and Pavlov), Cognitive (eg. Miller and Gardner) and

Constructivist (eg. Vygotsky and Bruner). There were 16 pairs choosing Behaviourist theorists, 10 pairs choosing Constructivist theorists and 3 pairs choosing Cognitive theorists. Within these 3 main categories,

there were more than 2 pairs of groups who wrote on the same theorist. Once the pairs were put into their respective Learning Theory Groups, group leaders were elected. Three types of group leaders were elected: 
1. 1 Overall Learning Theory Group Leader (OGL), who would be responsible for the final website, and the creation of the Learning Theories web page.

2. 3 Learning Theory Group Leaders (LGLs), who were in charge of overseeing the development of their Learning Theory websites and all the subgroups of theorists in their category.

3. 7 subgroup Leaders (SGLs), which are formed when similar Learning Theorist pairs were combined to form subgroups. For example, pairs who wrote about Pavlov would now combine to form the Pavlov subgroup, from which they would now elect a Pavlov subgroup leader. The same process was undertaken to form the subgroups in the Constructivist (Papert, Piaget, Vygotsky and Jonassen) and Cognitive (Gardner and Miller) groups. In total, there were 3 subgroups for Behaviourism, 4 subgroups for

Constructivism and 2 subgroups for Cognitivism. However, there were only 7 SGLs, as the Cognitive group, which was made up of only 6 members, opted not to have any SGLs but use their LGL only.

The newly formed subgroup members would now have to discuss their research papers and organise the information on their theorists. The modified content on the learning theorist from each subgroup would then be passed to the respective SGLs. The SGLs had responsibility for communicating the website tasks from the LGL to their members, collecting the reports written by their subgroup pairs in Stage 1, summarising and editing the materials, and compiling them to create their subgroup web pages. All the subgroup web pages are then given to the LGL, who compiled them to create their Learning Theory website. These groups were given 4 weeks to complete the task.

- Stage 3: Overall Learning Theory web page. The SGLs compiled the web pages and handed them to the respective LGLs, who then created their individual Learning Theory website, complete with their respective theorists' web pages. The 3 websites are then given to the OGL, who created the overall Learning Theory web Home page, and linked the 3 main Learning Theory websites. The entire website was submitted to the lecturer and uploaded on the class server to be accessed by the class. They were given 2 weeks to complete this task.

Throughout the duration of the 9-week project, students also met outside their class times for about 1 hour each to discuss their strategies and decisions. Since scheduling meetings posed some problems for some groups, many scheduled their meetings via Yahoo! Messenger, emails, and even through telephone conversations. Some time was also allocated during their lecture classes to attend to group meetings and discussions, 


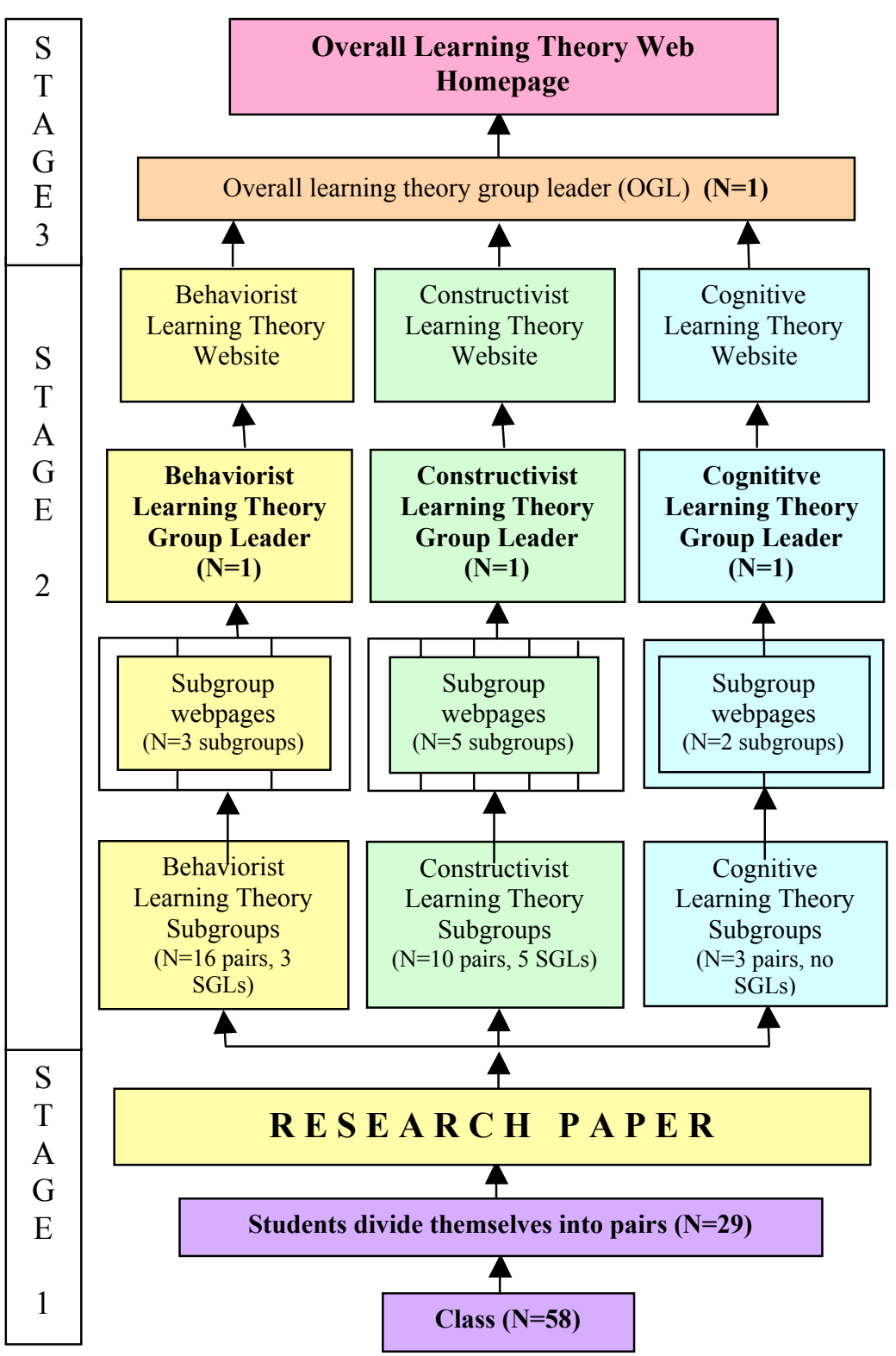

Figure 1: The class development process 
with the lecturer present as an external consultant and facilitator. Figure 1 illustrates the development process for this class.

\section{Phase 4: Executing the course}

The softwares that were used to create the final website took advantage of the students' existing skills in developing multimedia applications and included Macromedia Flash and Dreamweaver, and Adobe Photoshop. The groups also met once a week for consultation with the lecturer in order to discuss their ideas and concepts. At the end of the third week, these subgroups submitted their research papers, together with a progress report of their meetings, decisions, problems and solutions.

\section{Phase 5: Presentation and reflection}

At the end of the project, the groups turned in their respective website, with the OGL turning in the overall Learning Theories Homepage. The LGLs made the presentations in front of the class as well as the lecturer, and showed the class their group's website and content and commented on any issues or concerns they had faced during the task. After the presentation, the groups handed in their CDs which contained their respective websites, as well as their final reports, for assessment and evaluation.

\section{Phase 6: Assessment and evaluation}

The assessments of the project were done formatively. Each phase of the project was accompanied by a group progress report and member journal, so that their learning process can be assessed. The research papers were assessed on the following criteria:

1. Depth of content

2. Division of tasks and team effort (for group work assessment)

3. References

The final website was assessed on the following criteria:

1. Interactivity, links and navigation

2. Design and interface

3. Clarity of content

4. Depth of content presentation

5. Ability to write about the Learning Theory and its theorists

In terms of assessment, more weight was given to the collaborative group processes (teamwork, group management, division of tasks, organisation, etc.) and process skills, followed by the quality of content, and last by the technicalities of the websites. 


\section{The role of the teacher, student and technology}

In this design for cooperative learning, the role of the teacher is one that is somewhat "hands off", in terms of being involved in the group's decision making dynamics. In particular, the teacher moves from being the sole expert in the class to an external consultant in the learning environment. Since the students in these cooperative learning environments are autonomous from the teacher, they are solely responsible for the negotiations and the learning outcomes of the group. The teacher becomes the "guide on the side", providing consultations when needed and not playing a highly active role in the group's management process. Instead, the teacher plays an important role in structuring the course, monitoring the progress, and in providing a theoretical foundation to enable them to have a basic understanding of the course. Students, on the other hand, were solely responsible for the achievement and implementation of their group objectives, which is in line with the constructivist learning approach.

Table 1: The role of the teacher, students and technology in the cooperative learning environment

\begin{tabular}{|c|c|c|}
\hline Role of the teacher & Role of the student & Role of technology \\
\hline $\begin{array}{l}\text { - Provided instruction } \\
\text { and prerequisite } \\
\text { knowledge to } \\
\text { students } \\
\text { - Prescribed the group } \\
\text { project and content } \\
\text { - Responsible for } \\
\text { monitoring and } \\
\text { evaluating task and } \\
\text { process outcomes of } \\
\text { students } \\
\text { - External consultant } \\
\text { to the groups } \\
\text { - Used Web } \\
\text { technology to modify } \\
\text { curriculum and } \\
\text { update materials and } \\
\text { keep in touch with } \\
\text { students } \\
\text { - Verified Web links of } \\
\text { the students in } \\
\text { research papers } \\
\text { - Assessed students } \\
\text { formatively }\end{array}$ & $\begin{array}{l}\text { - Student group was } \\
\text { autonomous and } \\
\text { solely responsible for } \\
\text { the decision making } \\
\text { and negotiations in } \\
\text { the group } \\
\text { - Student groups } \\
\text { responsible for } \\
\text { learning outcomes } \\
\text { and internal group } \\
\text { management } \\
\text { - Conducted meetings } \\
\text { to determine best } \\
\text { possible solution to } \\
\text { solving group tasks } \\
\text { Conducted and } \\
\text { acquired research } \\
\text { information using the } \\
\text { Web } \\
\text { Solved and managed } \\
\text { group dynamics and } \\
\text { conflicts, and worked } \\
\text { cooperatively with } \\
\text { team members and } \\
\text { group leaders }\end{array}$ & $\begin{array}{l}\text { - Students used the } \\
\text { Web to conduct } \\
\text { research } \\
\text { - Students used } \\
\text { email, Yahoo! } \\
\text { Messenger and } \\
\text { Yahoo! Groups to } \\
\text { conduct meetings } \\
\text { and exchange files } \\
\text { and information } \\
\text { with each other } \\
\text { - Web } \\
\text { communication and } \\
\text { collaboration tools } \\
\text { were also used for } \\
\text { social interactions } \\
\text { among group } \\
\text { members } \\
\text { Web authoring } \\
\text { tools were used to } \\
\text { create the final } \\
\text { product, the } \\
\text { website. }\end{array}$ \\
\hline
\end{tabular}




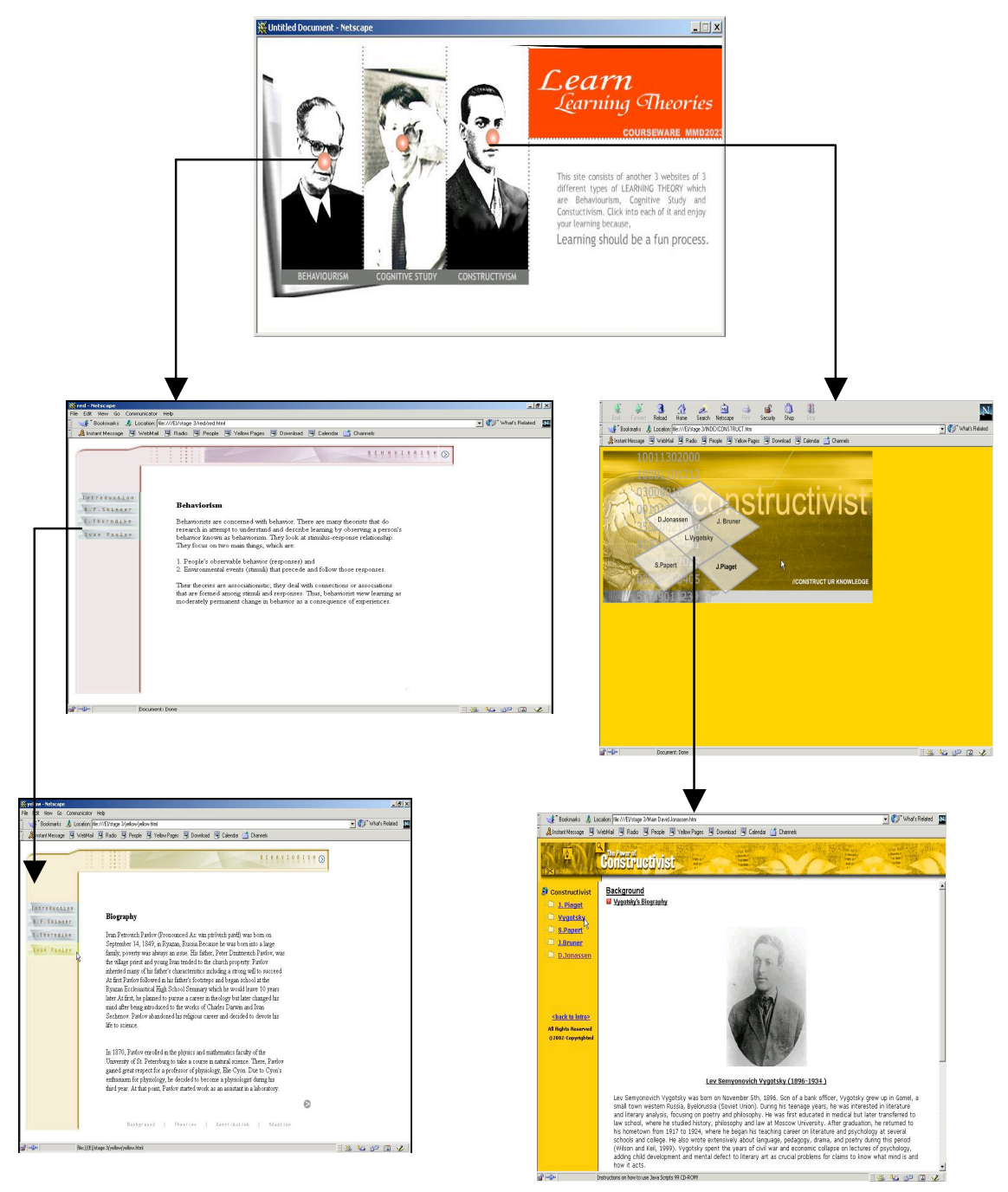

Figure 2: Students' product outcome

The technology in this environment acts as both a communicative and a learning platform for the students and the teacher. As a teaching and learning medium, the teacher used the technology to create the technology based instruction for the class lectures. Web authoring technologies like Macromedia Flash and Adobe Image Ready were made available in the labs to help them create their websites. As a communicative tool, the web technologies were utilised to help the teacher keep in touch with the 
students and to house the students' website, as well as making it accessible to them. Students also used the web technologies to help them overcome communication problems such as inability to schedule and conduct physical meetings, updating members on new information, sharing ideas, conducting asynchronous discussions, and posting queries. Yahoo! Messenger (for real time chats) and Yahoo! Groups (for group discussions) were the popular web communication tools used, second to emails. Table 1 depicts the role of the teacher, students and technology.

\section{Student learning outcomes}

Overall, students did well in the class, with $19 \%$ scoring As, $64 \%$ Bs, and $17 \% \mathrm{Cs}$ in their final grades. Formative assessments were made throughout the 9 weeks to measure students' learning processes and 2 types of learning outcomes were examined in this study: Product learning outcomes and Process learning outcomes.

\section{Product outcomes}

To evaluate students' product learning outcomes, the products of their project, which were the research papers, the websites and the corresponding learning theory webpages, were examined. Here, students would have to demonstrate their competency in completing the assigned tasks, which are the research papers (at the Stage 1 level) and the website (Stage 2 and Stage 3 levels). Figure 2 illustrates the learning product outcomes of students from the study.

\section{Process outcomes}

Process outcomes, on the other hand, involved assessing how students responded to this cooperative group based learning project. In particular, they needed to demonstrate skills in teamwork and leadership, communication, project and group management, decision making and presentation. Therefore, group journals and progress reports were examined, and groups were required to give a presentation at the end of the project completion date. The groups' journals revealed several activities that took place in the course of the project. Firstly, owing to their busy schedules and problems in meeting up for group discussions, many of the groups in the study used the class times, and also the web, to conduct their group meetings. In particular, all 3 Learning Theory Groups used emails to disseminate information among members and Yahoo! Messenger to conduct chats. Figure 3 depicts some of the groups in discussions during the class period and Figure 4 is an example of a group's communications on a discussion board. 


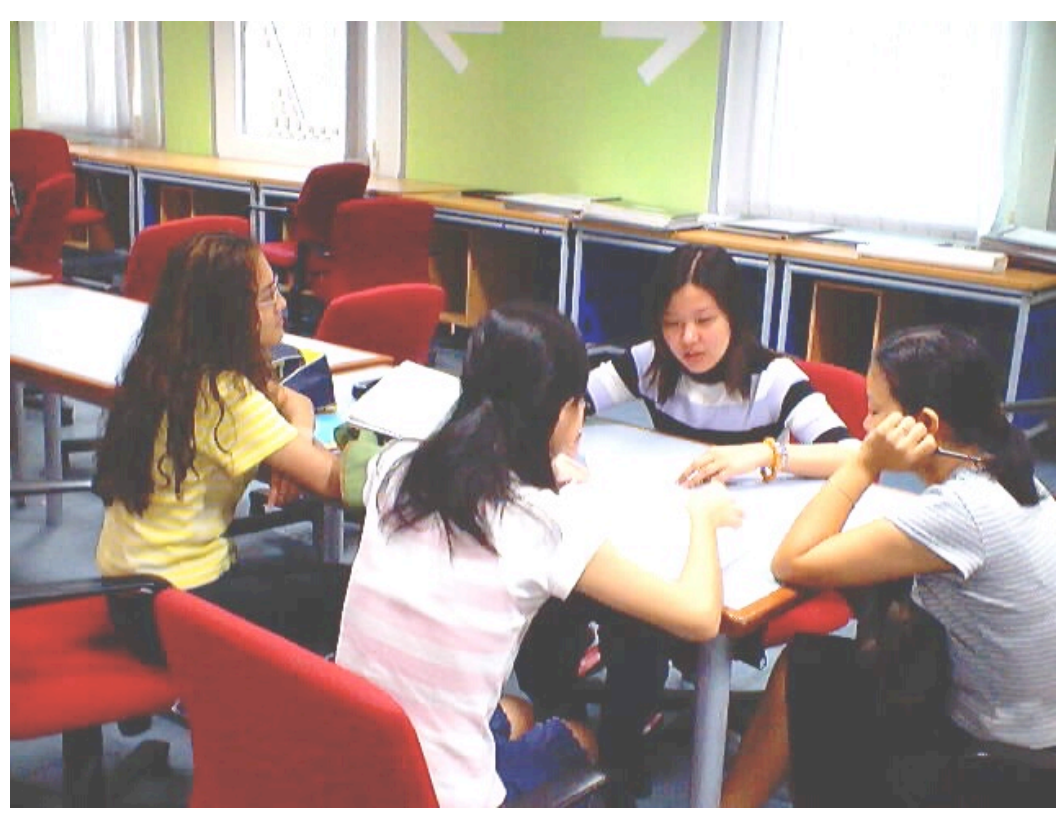

Figure 3: One student team in discussion over the project

\section{Survey results}

Students were given a survey to assess their attitudes towards working in this cooperative learning environment. The results of the study, as evidenced by the survey results and students' comments and feedback are presented here.

Specifically, students' perceptions and attitudes towards this cooperative learning environment were measured through their reports on the following cooperative constructs in the survey: 1) Teamwork, and communication skills, 2) Project management, 3) Capability to perform, and 4) Personal attitudes.

The students were given a 13 item survey, adapted from Diamond (1998) and Angelo \& Cross (1993), at the end of their task, to assess their attitudes towards doing the project and working in their respective teams during the respective phases. The reliability of the survey, using the Cronbach alpha coefficient, was 0.8673 , indicating satisfactory levels of internal consistency (Lim, Khine, Hew, Wong, Shanti \& Lim, 2003; DeVellis, 1991). 


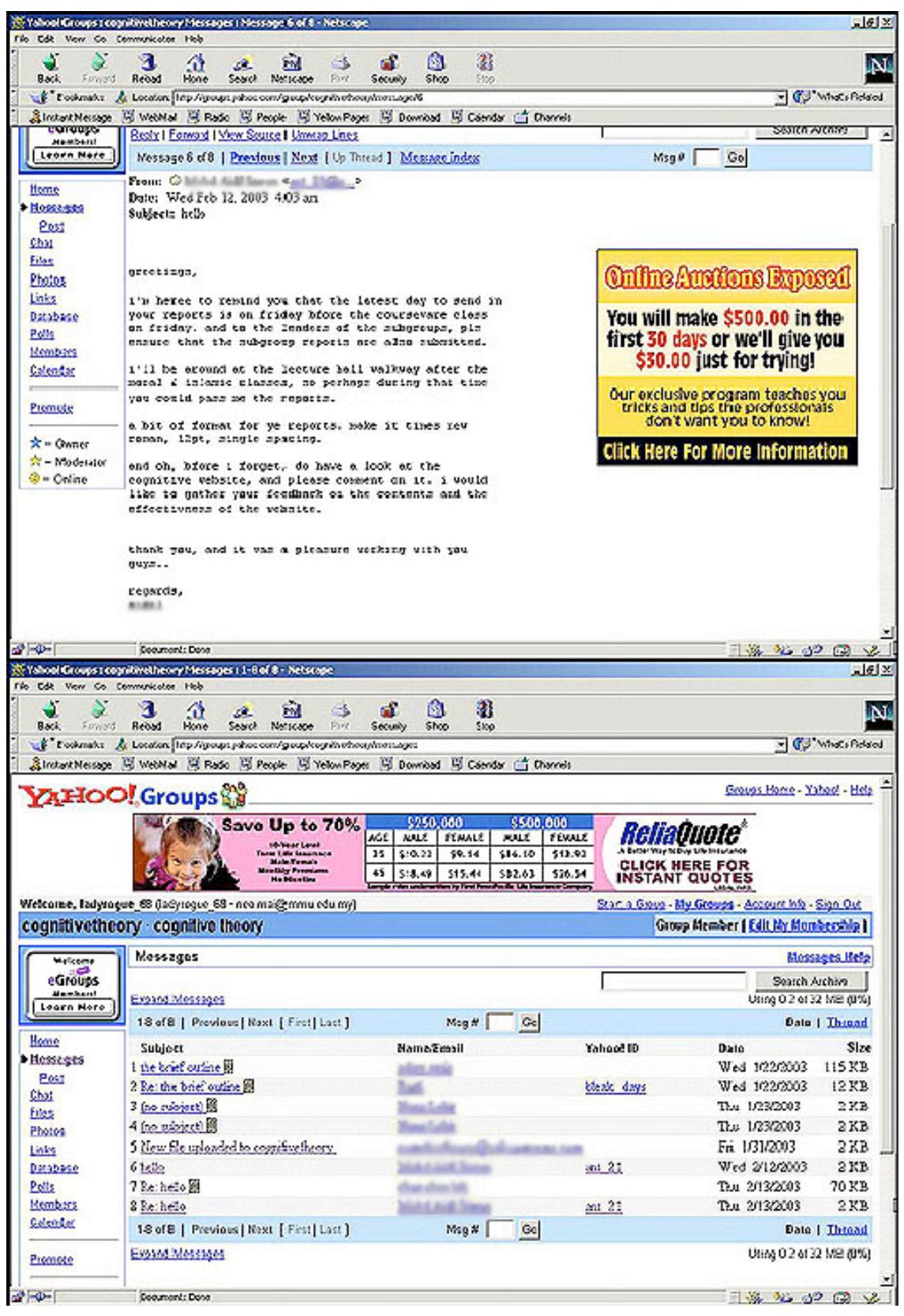

Figure 4: Students' communication on Yahoo! Groups discussion board 
The survey was measured on a 5 point Likert scale, with $1=$ Strongly Disagree (SDA), 2 = Disagree, 3 = Undecided, $4=$ Agree, and $5=$ Strongly Agree. Table 2 illustrates the means and the number of student responses (in percentages, \%) on the various survey items.

Table 2: Means and percentage responses on cooperative survey items for this cooperative learning environment $(\mathrm{N}=47)$

\begin{tabular}{|c|l|c|c|}
\hline \multicolumn{2}{|c|}{ Survey items } & Mean $(\mathrm{m})$ & $\%^{*}$ \\
\hline 1. & We were able to achieve our group goals & 4.83 & 85.1 \\
\hline 2. & Our group leader was very effective & 4.11 & 85.1 \\
\hline 3. & I enjoyed collaborating with team members & 3.89 & 76.6 \\
\hline 4. & I was able to contribute well to the project & 3.89 & 78.7 \\
\hline 5. & The collaboration enhanced my learning of the topic & 3.81 & 70.2 \\
\hline 6. & My group members contributed well to the project & 3.81 & 66.0 \\
\hline 7. & The collaboration was a challenge but I enjoyed it & 3.77 & 66.0 \\
\hline 8. & My group was able to work together effectively & 3.77 & 63.8 \\
\hline 9. & We were able to solve our problems as a group & 3.70 & 63.8 \\
\hline 10. & I found the collaboration very motivating & 3.57 & 57.4 \\
\hline 11. & My group communicated well with each other & 3.55 & 57.4 \\
\hline 12. & I learn more from the collaboration than on my own & 3.49 & 53.2 \\
\hline 13. & $\begin{array}{l}\text { My group taught me some things I would not have } \\
\text { learnt on my own }\end{array}$ & 3.47 & 51.1 \\
\hline *\% response for an item is the percentage of students who responded '4' or '5' \\
\hline
\end{tabular}

As shown in the table, the majority of the class reported favourable attitudes and perceptions in the surveys. Therefore, within this cooperative learning environment, several cooperative constructs (and skills) can be assessed.

\section{Teamwork and communication skills}

Items 4, 6, 8, 9 and 11 in the survey were used to measure students teamwork, leadership and communication skills (see Table 2). This would encompass how well the students worked together as a group, and solved their group problems. The study reported high means on these items. $78.7 \%$ of students reported that they contributed well to the project, (Item $4, \mathrm{~m}=3.89)$. These groups also reported that their group members contributed well to the project, Item $6,(\mathrm{~m}=3.81, \%$ response $=66 \%)$. In terms of being able to work together well and effectively, Item 8, groups reported a mean of 3.77 (\% response $=63.8)$. Embedded in this construct of teamwork is the ability to also solve group problems, Item 9 . Here $63.8 \%$ of student reported a mean of 3.70 indicating that the ability to solve problems was high. Groups also reported a fairly high mean for communication skills, Item 11, within the group. In particular, $57.4 \%$ of students reported a mean of 3.55 . 


\section{Project management}

Project management skills were measured by items 1 and 2 in the survey (see Table 2), which were items that asked students about their ability to complete their group tasks, and the role played by their group leader. Again the means reported here were quite very high. $85.1 \%$ of students reported a mean of 4.83 on the ability to achieve their group goals (Item 1 ). In terms of the effectiveness of the group leader, Item $2,85.1 \%$ of students reporting a mean of 4.11 .

\section{Ability to perform}

Items 5, 12 and 13 sought to measure students' ability to perform within the cooperative setting (see Table 2). Both items looked at how much students learnt from the project and whether they felt that they gained more skills from their group than on their own. In terms on enhancing their learning, Item $5,70.2 \%$ of students reported a mean of 3.81 , indicating that students found that their learning process was enhanced by the project. 53.2\% reported that they did learn more from the group than if they were to do the task on their own (Item 12, $\mathrm{m}=3.49$ ). Over half of the class felt that their groups did teach them some things which they would not have learnt on their own (Item $13, \mathrm{~m}=3.47, \%$ response $=51.1 \%$ ).

\section{Personal attitudes}

The survey also tried to gauge students' personal attitudes towards the group project, in terms of their personal enjoyment and motivation. Items 3,7 and 10, sought to measure this construct. Students reported high means for Item 3, $(m=3.89, \%$ response $=76.6 \%)$ indicating that they enjoyed cooperating with their team members. Students also found the project rather challenging but enjoyed doing it (Item 7), with $66 \%$ of students reporting a mean of 3.77. About the same percentage of students found the project to be motivating, Item $10(\mathrm{~m}=3.57$, \% response $=57.4 \%)$.

\section{Students' feedback}

The survey also asked two open ended questions, to obtain a richer feedback from student's via their written comments on the following:

Question 1: Give example(s) of something you learned from the group that you would not have learned working alone.

Question 2: What problems did your group face and how did you solve them?

Analysis of the written comments revealed that students found the project enhanced their teamwork, communication and project management skills. 
Tables 7 and 8 list some of the comments for Questions 1 and 2, respectively (these comments are in the students' own words and not modified for grammatical errors).

Table 3: Students' comments for Question 1

\begin{tabular}{|c|c|}
\hline \multicolumn{2}{|l|}{$\begin{array}{l}\text { westion 1: Give example(s) of something you learned from the group that you } \\
\text { would not have learned working alone. }\end{array}$} \\
\hline 1. & "The thing I learn from my group is new ideas." \\
\hline 2. & "Working attitudes. Some of them are really good in team work." \\
\hline 3. & "Learning new software such as Adobe Image ready from my group \\
members which I never learnt before."
\end{tabular}

As can be seen from the study, students found that working in a group helped them in managing their time, enhancing their communication skills and team spirit, and improving their understanding of the subject matter, as well as in conducting research. Many found that working in a group helped them handle the workload better, and provided them with technical help. In the study, students expressed the need to communicate, 
cooperate and exercise tolerance and patience when working with other people in a group, The cooperation and collaboration needed to complete their individual tasks were required so as to ensure the smooth management and attainment of the group's goals. They expressed concern over a possible "domino effect", whereby one member's delay would greatly affect the entire group's time schedule and work progress. Some students also expressed a "learning by observing" attitude by watching how their group leader handled their group. In this instance, working in a group gave them an insight on what it would be like to be the leader of a group and what skills were required to manage a group, something they could use when faced with such a task in the future.

Table 4: Students' comments for Question 2

Question 2: What problems did your group face and how did you solve them? 1. "Time-we had not enough time."

2. "We are lacking our time to meet and discuss together but we try to met by a day \& divide the jobs."

3. "Hard to get members to meet together."

4. "Knowledge about Dreamweaver not enough."

5. "Hard to get together with a group member because some of them stay off campus."

6. "Problem - difficult to set a meeting. Solutions - only the group leaders go for the meeting then they tell the other members what to do."

7. "To gathering for discussion. Have a meeting after class."

8. "Problem to gather together for discussion. The solution is to discuss online and break into small group for discussion." (OGL) (OGL=Overall Group Leader)

9. "Time management."

10. "Hard to handle such big group."

11. "Problem to keep in touch with other group members at first but then it was solve by doing the subgrouping."

12. "There are so many members, hard to divide the work. Select a person to contact others."

13. "Lack of leadership and initiative to make decision."

14. "Insufficient time, we divided task to everyone to speed things up."

15. "Some groupmates did not contribute \& became parasit."

16. "Different idea, we try to negotiate with each other."

17. "..our research topic is a new field of research and many of us find a bit difficulty. We manage to solve that by breaking information to small parts and take the main idea behind each part."

18. "Planning out the time management. Cause if there was a meeting at least one member won't be able to come for it. We gave out work and gave a due date to it. So everyone did their part and handed them in on time." 


\section{Discussion}

In this group based, cooperative learning, students learn by cooperating and interacting with their peers. Unlike traditional teacher directed instruction, where students learn individually and compete with one another in learning, cooperative learning requires cooperation and collaboration among students in order to achieve the group learning goals. It encourages cooperative activities in the learning process, teamwork, and communication skills in learning. This learning environment also was placed in an authentic learning situation in that they had to translate the information they had researched on Learning Theories and their corresponding theorists, into educational web pages and websites to enhance the learning process of the whole class. Such an authentic setting invariably promotes highly engagement levels amongst students and facilitates their cooperative learning activities.

From the survey, and students' comments and feedback in this study, it can be observed that multimedia mediated, cooperative learning enhanced students' teamwork and communication skills, project management, and improved their personal attitudes in learning, enabling them to enjoy doing the project and increasing their motivational levels in learning. The project also helped students to increase their team spirit, and the 'learning by doing' process enhanced their understanding of the subject matter and the conduct of their investigations and research.

In this cooperative learning environment, multimedia was used by the students to design and construct a multimedia project, which was then deployed over the web. This process of learning is more geared towards the constructivist learning perspective where students learn by constructing knowledge and participate actively in their learning process (Jonassen, Peck \& Wilson, 1999). As such, the learning process becomes the central focus, and not the content (Neo, 2003). In addition, the use of a multimedia project enabled them to be more engaged and motivated (Agnew, Kellerman \& Meyer, 1996) The findings of this study are consistent with the results reported by Neo \& Neo (2001), who found similar results whereby students' motivation and engagement levels were heightened through the use of a multimedia, web based group project.

This provides students with an opportunity to be involved in learner centred activities, while the teacher becomes a facilitator of learning, acting as a consultant and guide to the students' learning. The technology used enables and makes the learning process feasible. The requirement to create web based output resulted in students taking advantage of several web based technologies, not only for development, but also for cultivating 
cooperative and collaborative activities, such as conducting discussions on bulletin boards (Hong, Lai \& Holton, 2001; McLoughlin, 2002; Treleaven, 2003) among their peers, which can be accessed by the teacher, and through the sharing of files electronically.

Feedback from the students also showed that they found the cooperative activities beneficial to their own individual learning process, as well as to the group as a whole. Many reported that the project allowed them to learn much more from working in a group environment than working alone. This is consistent with McLoughlin's (2002) position that "learning tasks [that] made use of technology... fostered collaboration, problem solving and interdependent learning." In particular, it was observed that the varying of group membership, from small pairs to larger subgroups, was effective in enabling students to consider the goals of the class as a whole, thus engaging them to work together cohesively toward that common goal, which is the essence of cooperative learning. Overall, the design of this learning environment was successful in that all Learning Theory groups were able to complete and present their website. The SGLs, LGLs and OGL, who were selected via an election by their peers or on a voluntary basis, were integral to the organisation and success of the project. This can be seen from their presentations and journals, as they documented their role in the organising and synthesising their group's activities in order to complete their website.

\section{Conclusion}

This study on group based, cooperative learning on the web has shown that its impact on student learning is considerable. It emphasises cooperation and collaboration in student learning, rather than individual competition, as is practised in the traditional educational system. This study has shown that this model of learning has helped students working in groups learn to manage their time and project, enhance their communication skills and team spirit, raise their level of motivation in learning, and increase their understanding of the subject matter. Its limitations are that sometimes it results in group management problems, where groups find it difficult to meet for meetings due to their schedules, and may not be able to agree on ideas for completing their group project, and at times, it faces non-cooperation problems among group members. However, despite all these problems, this multimedia mediated, cooperative learning can be regarded as a viable and constructive instructional method in our repertoire of teaching and learning models. 


\section{References}

Agnew, P. W., Kellerman, A. S. and Meyer, J. (1996). Multimedia in the Classroom. Boston: Allyn and Bacon.

Angelo, T. and Cross, K. P. (1993). Classroom Assessment Techniques: A Handbook for College Teachers. SF: Jossey Bass, Inc.

Arends, R. I. (1997). Classroom Instruction and Management. NY: McGraw-Hill, pp. 110-111.

Dewey, J. (1916). Democracy and Education. New York: Macmillan.

DeVellis, R. F. (1991). Scale Development: Theory and Applications. Newbury Park: Sage Publications.

Diamond, R. M. (1998). Designing and Assessing Courses and Curricula: A Practical Guide. SF: Jossey Bass, Inc.

Herrington, J., Oliver, R. and Reeves, T.C. (2003). Patterns of engagement in authentic online learning environments. Australian Journal of Educational Technology, 19(1), 59-71. http:/ / www.ascilite.org/ajet/ajet19/ herrington.html

Hong Kian-Sam, Lai Kwok-Wing and Holton, D. (2001). Web based learning environments: Observations from a Web based course in a Malaysian context. Australian Journal of Educational Technology, 17(3), 223-243.

http: / / www.ascilite.org.au/ajet/ ajet17/hong.htm

Johnson D. W. and Johnson R. T. (1986). Learning together and alone: Cooperation, competition and individualization (2nd ed). Englewood Cliffs, NJ: Prentice-Hall.

Johnson, D. W., Johnson, R. T. \& Smith, K. A. (1991). Active learning: Cooperative learning in the college classroom. Edina, MN: Interaction Book Company.

Johnson, D. W. and Johnson, R. T. (1994). Joining together: Group theory and group skills ( 5 th ed). Boston: Allyn \& Bacon.

Jonassen, D. H., Peck, K. L. and Wilson, B. G. (1999). Learning With Technology: A Constructivist Perspective. NJ: Merrill/ Prentice Hall.

Lim, C. P., Khine, M.S., Hew, T., Wong, P., Shanti, D., and Lim, B. (2003). Exploring critical aspects of information technologies integration in Singapore schools. Australian Journal of Educational Technology, 19(1), 1-24.

http:/ / www.ascilite.org.au/ajet/ajet19/lim.html

McLoughlin, C. (2002). Computer supported teamwork: An integrative approach to evaluating cooperative learning in an online environment. Australian Journal of Educational Technology, 18(2), 227-254.

http:/ / www.ascilite.org.au/ajet/ajet18/mcloughlin.html 
Neo, K. T. K. and Neo, M. (2001). A constructivist learning experience: Reconstructing a web site using web based multimedia authoring tools. Australian Journal of Educational Technology, 17(3), 330-350.

http:/ / www.ascilite.org.au/ajet/ajet17/neo.html

Neo, K. (2003). Using multimedia in a constructivist learning environment in the Malaysian classroom. Australian Journal of Educational Technology, 19(3), 293-310. http: / / www.ascilite.org.au/ajet/ajet19/neo.html

Slavin, R. E. (1990). Ability grouping and student achievement in secondary schools. A best evidence synthesis. Review of Educational Research, 60, 471-499.

Slavin, R. E. (1991). Student team learning: A practical guide to cooperative learning (3rd ed). Washington,DC: National Educational Association.

Slavin R. E. (1994). A practical guide to cooperative learning. Boston: Allyn \& Bacon.

Tapscott, D. (1998). Growing Up Digital: The Rise of the Net Generation. NY: McGrawHill.

Thelan, H. A. (1954). Dynamics of groups at work. Chicago: University of Chicago Press.

Thelan, H. A. (1963). Education and the human quest. NY: Harper and Row.

Treleaven, L. (2003). Evaluating a communicative model for web mediated collaborative learning and design. Australian Journal of Educational Technology, 19(1), 100-117. http:/ / www.ascilite.org.au/ajet/ ajet19/treleaven.html

Mai Neo is a Lecturer in the Centre for Innovative
Education (CINE), Faculty of Creative Multimedia,
Multimedia University, Cyberjaya, Selangor, Malaysia.
Email: kneo@pc.jaring.my
Tel: +60 356357817 Fax: +60356357817

